\title{
Questes
}

vestes Revue pluridisciplinaire d'études médiévales

3 | 2003

Les bruits de la ville

\section{Le Musicien déchu}

\section{Marie-Edith de Feuardent}

\section{OpenEdition}

\section{Journals}

Édition électronique

URL : http://journals.openedition.org/questes/2328

DOI : 10.4000/questes.2328

ISSN : 2109-9472

\section{Éditeur}

Les Amis de Questes

\section{Édition imprimée}

Date de publication : 15 mars 2003

Pagination : 10-11

ISSN : 2102-7188

\section{Référence électronique}

Marie-Edith de Feuardent, «Le Musicien déchu », Questes [En ligne], 3 | 2003, mis en ligne le 01 janvier 2014, consulté le 19 septembre 2020. URL : http://journals.openedition.org/questes/2328 ; DOI : https://doi.org/10.4000/questes.2328

Ce document a été généré automatiquement le 19 septembre 2020.

(C) Association des amis de «Questes » 


\title{
Le Musicien déchu
}

\author{
Marie-Edith de Feuardent
}

NOTE DE L'ÉDITEUR

Cet article n'a pas encore fait l'objet d'une autorisation de publication.

INDEX

Mots-clés : bruit, Enfer, diable, musicien, péché, harmonie, moine, cacophonie

Keywords : noise, Hell, devil, musician, sin, monk, harmony, cacophony 